\title{
Tumour necrosis factor (TNF) receptor family in GtoPdb v.2021.3
}

David MacEwan ${ }^{1}$

1. University of Liverpool, UK

\begin{abstract}
Dysregulated TNFR signalling is associated with many inflammatory disorders, including some forms of arthritis and inflammatory bowel disease, and targeting TNF has been an effective therapeutic strategy in these diseases and for cancer immunotherapy [5, 6, 49].
\end{abstract}

\section{Contents}

This is a citation summary for Tumour necrosis factor (TNF) receptor family in the Guide to Pharmacology database (GtoPdb). It exists purely as an adjunct to the database to facilitate the recognition of citations to and from the database by citation analyzers. Readers will almost certainly want to visit the relevant sections of the database which are given here under database links.

GtoPdb is an expert-driven guide to pharmacological targets and the substances that act on them. GtoPdb is a reference work which is most usefully represented as an on-line database. As in any publication this work should be appropriately cited, and the papers it cites should also be recognized. This document provides a citation for the relevant parts of the database, and also provides a reference list for the research cited by those parts. For further details see [8].

Please note that the database version for the citations given in GtoPdb are to the most recent preceding version in which the family or its subfamilies and targets were substantially changed. The links below are to the current version. If you need to consult the cited version, rather than the most recent version, please contact the GtoPdb curators.

\section{Database links}

Tumour necrosis factor (TNF) receptor family

https://www.guidetopharmacology.org/GRAC/FamilyDisplayForward?familyId=334

Introduction to Tumour necrosis factor (TNF) receptor family

https://www.guidetopharmacology.org/GRAC/FamilyIntroductionForward?familyId=334

Receptors

TNFR1(tumor necrosis factor receptor 1)

https://www.guidetopharmacology.org/GRAC/ObjectDisplayForward?objectId=1870

TNFR2(tumor necrosis factor receptor 2)

https://www.guidetopharmacology.org/GRAC/ObjectDisplayForward?objectId=1871 lymphotoxin $\beta$ receptor

https://www.guidetopharmacology.org/GRAC/ObjectDisplayForward?objectId=1872

OX40

https://www.guidetopharmacology.org/GRAC/ObjectDisplayForward?objectId=1873

CD40

https://www.guidetopharmacology.org/GRAC/ObjectDisplayForward?objectId=1874

Fas

https://www.guidetopharmacology.org/GRAC/ObjectDisplayForward?objectId=1875 decoy receptor 3

https://www.guidetopharmacology.org/GRAC/ObjectDisplayForward?objectId=2322 CD27

https://www.guidetopharmacology.org/GRAC/ObjectDisplayForward?objectId=1876 CD30

https://www.guidetopharmacology.org/GRAC/ObjectDisplayForward?objectId=1877 
4-1BB

https://www.guidetopharmacology.org/GRAC/ObjectDisplayForward?objectId=1878 DR4(death receptor 4)

https://www.guidetopharmacology.org/GRAC/ObjectDisplayForward?objectId=1879 DR5(death receptor 5)

https://www.guidetopharmacology.org/GRAC/ObjectDisplayForward?objectId=1880 decoy receptor 1

https://www.guidetopharmacology.org/GRAC/ObjectDisplayForward?objectId=2323 decoy receptor 2

https://www.guidetopharmacology.org/GRAC/ObjectDisplayForward?objectId=2324 RANK(receptor activator of NF-kappa B)

https://www.guidetopharmacology.org/GRAC/ObjectDisplayForward?objectId=1881 OPG(osteoprotegerin)

https://www.guidetopharmacology.org/GRAC/ObjectDisplayForward?objectId=1882 DR3(death receptor 3)

https://www.guidetopharmacology.org/GRAC/ObjectDisplayForward?objectId=1883 TWEAK receptor

https://www.guidetopharmacology.org/GRAC/ObjectDisplayForward?objectId=1884 TACI

https://www.guidetopharmacology.org/GRAC/ObjectDisplayForward?objectId=1885 BAFF-R(BAFF receptor)

https://www.guidetopharmacology.org/GRAC/ObjectDisplayForward?objectId=1886 HVEM(herpes virus entry mediator)

https://www.guidetopharmacology.org/GRAC/ObjectDisplayForward?objectId=1887 nerve growth factor receptor

https://www.guidetopharmacology.org/GRAC/ObjectDisplayForward?objectId=1888 BCMA(B cell maturation antigen)

https://www.guidetopharmacology.org/GRAC/ObjectDisplayForward?objectId=1889 GITR(glucocorticoid-induced TNF receptor)

https://www.guidetopharmacology.org/GRAC/ObjectDisplayForward?objectId=1890 TAJ(toxicity and JNK inducer)

https://www.guidetopharmacology.org/GRAC/ObjectDisplayForward?objectId=1891 RELT

https://www.guidetopharmacology.org/GRAC/ObjectDisplayForward?objectId=1892 DR6(death receptor 6)

https://www.guidetopharmacology.org/GRAC/ObjectDisplayForward?objectId=1893 TNFRSF22

https://www.guidetopharmacology.org/GRAC/ObjectDisplayForward?objectId=1894 TNFRSF23

https://www.guidetopharmacology.org/GRAC/ObjectDisplayForward?objectId=1895 ectodysplasin A2 isoform receptor

https://www.guidetopharmacology.org/GRAC/ObjectDisplayForward?objectId=1896 ectodysplasin 1, anhidrotic receptor

https://www.guidetopharmacology.org/GRAC/ObjectDisplayForward?objectId=2325

\section{References}

1. (2017) Sending CAR T Cells After Multiple Myeloma. Cancer Discov 7: OF9 [PMID:28588060]

2. Algate P, Clegg SJ, Craigen JL, Hamblim PA, Lewis AP, Mayes P, Parmar RS and WattamTAK. (2016) B cell maturation antigen (BCMA) binding proteins Patent number: US9273141B2.

3. Bidère N, Su HC and Lenardo MJ. (2006) Genetic disorders of programmed cell death in the immune system. Annu Rev Immunol 24: 321-52 [PMID:16551252]

4. Bienkowska J, Allaire N, Thai A, Goyal J, Plavina T, Nirula A, Weaver M, Newman C, Petri M and Beckman E et al.. (2014) Lymphotoxin-LIGHT pathway regulates the interferon signature in rheumatoid arthritis. PLOS ONE 9: e112545 [PMID:25405351]

5. Bremer E. (2013) Targeting of the tumor necrosis factor receptor superfamily for cancer immunotherapy. ISRN Oncol 2013: 371854 [PMID:23840967]

6. Brenner D, Blaser H and Mak TW. (2015) Regulation of tumour necrosis factor signalling: live or let die. Nat Rev Immunol 15: 362-74 [PMID:26008591]

7. Buchan SL, Rogel A and Al-Shamkhani A. (2018) The immunobiology of CD27 and OX40 and their potential as targets for cancer immunotherapy. Blood 131: 39-48 [PMID:29118006]

8. Buneman P, Christie G, Davies JA, Dimitrellou R, Harding SD, Pawson AJ, Sharman JL and Wu Y. (2020) Why data citation isn't working, and what to do about it Database 2020

[PMID:32367113]

9. Castigli E, Wilson SA, Garibyan L, Rachid R, Bonilla F, Schneider L and Geha RS. (2005) TACI is mutant in common variable immunodeficiency and IgA deficiency. Nat Genet 37: 829-34 
[PMID:16007086]

10. Cebada J, Perez-Santos M, Bandala C, Lara-Padilla E, Herrera-Camacho I, Rosas-Murrieta NH, Millán-Pérez Peña L, Monjaraz E, Flores A and Anaya-Ruiz M. (2021) OX40 agonists for cancer treatment: a patent review. Expert Opin Ther Pat 31: 81-90 [PMID:32945223]

11. Chang YH, Hsieh SL, Chen MC and Lin WW. (2002) Lymphotoxin beta receptor induces interleukin 8 gene expression via NF-kappaB and AP-1 activation. Exp Cell Res 278: 166-74 [PMID:12169272]

12. Chen X and Oppenheim JJ. (2017) Targeting TNFR2, an immune checkpoint stimulator and oncoprotein, is a promising treatment for cancer. Sci Signal 10 [PMID:28096506]

13. Chen X, Wu X, Zhou Q, Howard OM, Netea MG and Oppenheim JJ. (2013) TNFR2 is critical for the stabilization of the CD4+Foxp3+ regulatory $T$. cell phenotype in the inflammatory environment. J Immunol 190: 1076-84 [PMID:23277487]

14. Culp PA, Choi D, Zhang Y, Yin J, Seto P, Ybarra SE, Su M, Sho M, Steinle R and Wong MH et al.. (2010) Antibodies to TWEAK receptor inhibit human tumor growth through dual mechanisms. Clin Cancer Res 16: 497-508 [PMID:20068083]

15. Dhruv HD, Roos A, Tomboc PJ, Tuncali S, Chavez A, Mathews I, Berens ME, Loftus JC and Tran NL. (2016) Propentofylline inhibits glioblastoma cell invasion and survival by targeting the TROY signaling pathway. J Neurooncol 126: 397-404 [PMID:26559543]

16. Duhen R, Ballesteros-Merino C, Frye AK, Tran E, Rajamanickam V, Chang SC, Koguchi Y, Bifulco CB, Bernard B and Leidner RS et al.. (2021) Neoadjuvant anti-OX40 (MEDI6469) therapy in patients with head and neck squamous cell carcinoma activates and expands antigen-specific tumor-infiltrating T cells. Nat Commun 12: 1047 [PMID:33594075]

17. Ellmark P, Fritzell S, Furebring C, Petersson J, Säll A, Smith KE, Varas L, Von SL and Veitonmäki N. (2018) Novel antibodies and uses thereof Patent number: WO2018091740A2.

18. Eskiocak U, Guzman W, Wolf B, Cummings C, Milling L, Wu HJ, Ophir M, Lambden C, Bakhru P and Gilmore DC et al.. (2020) Differentiated agonistic antibody targeting CD137 eradicates large tumors without hepatotoxicity. JCI Insight 5: e133647 [PMID:32161196]

19. Fischer R, Marsal J, Guttà C, Eisler SA, Peters N, Bethea JR, Pfizenmaier K and Kontermann RE. (2017) Novel strategies to mimic transmembrane tumor necrosis factor-dependent activation of tumor necrosis factor receptor 2. Sci Rep 7: 6607 [PMID:28747780]

20. Fisher TS, Kamperschroer C, Oliphant T, Love VA, Lira PD, Doyonnas R, Bergqvist S, Baxi SM, Rohner A and Shen AC et al.. (2012) Targeting of 4-1BB by monoclonal antibody PF-05082566 enhances T-cell function and promotes anti-tumor activity. Cancer Immunol Immunother 61: 1721-33 [PMID:22406983]

21. Furihata K, Ishiguro Y, Yoshimura N, Ito H, Katsushima S, Kaneko E, Shimabe M, Mukai M, Watanabe R and Morishige T. (2021) A Phase 1 Study of KHK4083: A Single-Blind, Randomized, Placebo-Controlled Single-Ascending-Dose Study in Healthy Adults and an Open-Label MultipleDose Study in Patients With Ulcerative Colitis. Clin Pharmacol Drug Dev [PMID:33512065]

22. Gubernatorova EO and Tumanov AV. (2016) Tumor Necrosis Factor and Lymphotoxin in Regulation of Intestinal Inflammation. Biochemistry Mosc 81: 1309-1325 [PMID:27914457]

23. Gutierrez M, Moreno V, Heinhuis KM, Olszanski AJ, Spreafico A, Ong M, Chu Q, Carvajal RD, Trigo J and De Olza MO et al.. (2021) OX40 Agonist BMS-986178 Alone or in Combination With Nivolumab and/or Ipilimumab in Patients With Advanced Solid Tumors. Clin Cancer Res 27: 460-472 [PMID:33148673]

24. Haile WB, Echeverry R, Wu F, Guzman J, An J, Wu J and Yepes M. (2010) Tumor necrosis factorlike weak inducer of apoptosis and fibroblast growth factor-inducible 14 mediate cerebral ischemia-induced poly(ADP-ribose) polymerase-1 activation and neuronal death. Neuroscience 171: 1256-64 [PMID:20955770]

25. Hanson GJ, Vuletich JL, Bedell LJ, Bono CP, Howard SC, Welpy JW, Woulfe SL and Zacheis ML. (1996) Design of MHC class II (DR4) ligands using conformationally restricted imino acids at p3 and p5. Bioorg Med Chem Lett 6: 1931-1936

26. Hengeveld PJ and Kersten MJ. (2015) B-cell activating factor in the pathophysiology of multiple myeloma: a target for therapy? Blood Cancer J 5: e282 [PMID:25723853]

27. Heusser C, Neugebauer J, Schaadt E, Urlinger S and Woisetschlaeger M. (2010) Compositions and methods of use for therapeutic antibodies Patent number: WO2010007082A1.

28. Heusser C, Rush J and Vincent K. (2012) Silent fc variants of anti-cd40 antibodies. Patent number: WO2012065950.

29. Hipp S, Tai YT, Blanset D, Deegen P, Wahl J, Thomas O, Rattel B, Adam PJ, Anderson KC and Friedrich M. (2017) A novel BCMA/CD3 bispecific T-cell engager for the treatment of multiple myeloma induces selective lysis in vitro and in vivo. Leukemia 31: 1743-1751 [PMID:28025583]

30. Huseni M, Totpal K, Du C, Dalpozzo K, Zhu J, Rishipathak D, McNamara E, Jonshtone B, Hegde PS and Rhee I. (2014) Anti-tumor efficacy and biomarker evaluation of agonistic anti-OX40 antibodies in preclinical models Journal for Immunotherapy of Cancer 2: 105

31. Jacobs VL, Landry RP, Liu Y, Romero-Sandoval EA and De Leo JA. (2012) Propentofylline decreases tumor growth in a rodent model of glioblastoma multiforme by a direct mechanism on microglia. Neuro-oncology 14: 119-31 [PMID:22086978] 
32. Jacobs VL, Liu Y and De Leo JA. (2012) Propentofylline targets TROY, a novel microglial signaling pathway. PLoS ONE 7: e37955 [PMID:22649568]

33. Jeon YH, Lee JY and Kim S. (2012) Chemical modulators working at pharmacological interface of target proteins. Bioorg Med Chem 20: 1893-901 [PMID:22227462]

34. Jure-Kunkel, M, Hefta LJ, Santoro M, Ganguly S and Halk EL. (2005) Fully human antibodies against human 4-1bb (cd137) Patent number: WO2005035584.

35. Keshtvarz M, Salimian J, Yaseri M, Bathaie SZ, Rezaie E, Aliramezani A, Norouzbabaei Z, Amani J and Douraghi M. (2017) Bioinformatic prediction and experimental validation of a PE38-based recombinant immunotoxin targeting the Fn14 receptor in cancer cells. Immunotherapy 9: 387400 [PMID:28357912]

36. Kichev A, Eede P, Gressens P, Thornton C and Hagberg H. (2017) Implicating Receptor Activator of NF-kB (RANK)/RANK Ligand Signalling in Microglial Responses to Toll-Like Receptor Stimuli. Dev Neurosci 39: 192-206 [PMID:28402971]

37. Lee L, Bounds D, Paterson J, Herledan G, Sully K, Seestaller-Wehr LM, Fieles WE, Tunstead J, McCahon L and Germaschewski FM et al.. (2016) Evaluation of B cell maturation antigen as a target for antibody drug conjugate mediated cytotoxicity in multiple myeloma. Br J Haematol 174: 911-22 [PMID:27313079]

38. Makkouk A, Chester C and Kohrt HE. (2016) Rationale for anti-CD137 cancer immunotherapy. Eur J Cancer 54: 112-119 [PMID:26751393]

39. Nakagawa H, Iizuka H, Nemoto O, Shimabe M, Furukawa Y, Kikuta N and Ootaki K. (2020) Safety, tolerability and efficacy of repeated intravenous infusions of KHK4083, a fully human anti-OX40 monoclonal antibody, in Japanese patients with moderate to severe atopic dermatitis. J Dermatol Sci 99: 82-89 [PMID:32651105]

40. Ngo VN, Korner H, Gunn MD, Schmidt KN, Riminton DS, Cooper MD, Browning JL, Sedgwick JD and Cyster JG. (1999) Lymphotoxin alpha/beta and tumor necrosis factor are required for stromal cell expression of homing chemokines in B and T cell areas of the spleen. J Exp Med 189: 403-12 [PMID:9892622]

41. Ozkok A, Caliskan Y, Sakaci T, Erten G, Karahan G, Ozel A, Unsal A and Yildiz A. (2012) Osteoprotegerin/RANKL axis and progression of coronary artery calcification in hemodialysis patients. Clin J Am Soc Nephrol 7: 965-73 [PMID:22490874]

42. Papp KA, Gooderham MJ, Girard G, Raman M and Strout V. (2017) Phase I randomized study of KHK4083, an anti-OX40 monoclonal antibody, in patients with mild to moderate plaque psoriasis. J Eur Acad Dermatol Venereol 31: 1324-1332 [PMID:28556418]

43. Podar K and Pecherstorfer M. (2017) Current and developing synthetic pharmacotherapy for treating relapsed/refractory multiple myeloma. Expert Opin Pharmacother 18: 1061-1079 [PMID:28604120]

44. Purcell JW, Kim HK, Tanlimco SG, Doan M, Fox M, Lambert P, Chao DT, Sho M, Wilson KE and Starling GC et al.. (2014) Nuclear Factor $\mathrm{kB}$ is Required for Tumor Growth Inhibition Mediated by Enavatuzumab (PDL192), a Humanized Monoclonal Antibody to TweakR. Front Immunol 4: 505 [PMID:24409185]

45. Rahmanzadeh R, Weber MS, Brück W, Navardi S and Sahraian MA. (2018) B cells in multiple sclerosis therapy-A comprehensive review. Acta Neurol Scand 137: 544-556 [PMID:29512131]

46. Reusch U, Burkhardt C, Fucek I, Le Gall F, Le Gall M, Hoffmann K, Knackmuss SH, Kiprijanov S, Little M and Zhukovsky EA. (2014) A novel tetravalent bispecific TandAb (CD30/CD16A) efficiently recruits NK cells for the lysis of CD30+ tumor cells. MAbs 6: 728-39 [PMID:24670809]

47. Salzer U, Chapel HM, Webster AD, Pan-Hammarström Q, Schmitt-Graeff A, Schlesier M, Peter $\mathrm{HH}$, Rockstroh JK, Schneider P and Schäffer AA et al.. (2005) Mutations in TNFRSF13B encoding TACI are associated with common variable immunodeficiency in humans. Nat Genet 37: 820-8 [PMID:16007087]

48. Schreiber TH, Wolf D, Tsai MS, Chirinos J, Deyev VV, Gonzalez L, Malek TR, Levy RB and Podack ER. (2010) Therapeutic Treg expansion in mice by TNFRSF25 prevents allergic lung inflammation. J Clin Invest 120: 3629-40 [PMID:20890040]

49. Sedger LM and McDermott MF. (2014) TNF and TNF-receptors: From mediators of cell death and inflammation to therapeutic giants - past, present and future. Cytokine Growth Factor Rev 25: 453-72 [PMID:25169849]

50. Song Y, Margolles-Clark E, Bayer A and Buchwald P. (2014) Small-molecule modulators of the OX40-OX40 ligand co-stimulatory protein-protein interaction. Br J Pharmacol 171: 4955-69 [PMID:24930776]

51. Tai YT, Mayes PA, Acharya C, Zhong MY, Cea M, Cagnetta A, Craigen J, Yates J, Gliddon L and Fieles W et al.. (2014) Novel anti-B-cell maturation antigen antibody-drug conjugate (GSK2857916) selectively induces killing of multiple myeloma. Blood 123: 3128-38 [PMID:24569262]

52. Takahashi T, Tanaka M, Brannan CI, Jenkins NA, Copeland NG, Suda T and Nagata S. (1994) Generalized lymphoproliferative disease in mice, caused by a point mutation in the Fas ligand. 
Cell 76: 969-76 [PMID:7511063]

53. Torrey H, Butterworth J, Mera T, Okubo Y, Wang L, Baum D, Defusco A, Plager S, Warden S and Huang D et al.. (2017) Targeting TNFR2 with antagonistic antibodies inhibits proliferation of ovarian cancer cells and tumor-associated Tregs. Sci Signal 10 [PMID:28096513]

54. van de Ven K and Borst J. (2015) Targeting the T-cell co-stimulatory CD27/CD70 pathway in cancer immunotherapy: rationale and potential. Immunotherapy 7: 655-67 [PMID:26098609]

55. Vanamee ÉS and Faustman DL. (2017) TNFR2: A Novel Target for Cancer Immunotherapy. Trends Mol Med 23: 1037-1046 [PMID:29032004]

56. Wang EC. (2012) On death receptor 3 and its ligands.... Immunology 137: 114-6 [PMID:22612445]

57. Watanabe-Fukunaga R, Brannan CI, Copeland NG, Jenkins NA and Nagata S. (1992) Lymphoproliferation disorder in mice explained by defects in Fas antigen that mediates apoptosis. Nature 356: 314-7 [PMID:1372394]

58. Webb GJ, Hirschfield GM and Lane PJ. (2016) OX40, OX40L and Autoimmunity: a Comprehensive Review. Clin Rev Allergy Immunol 50: 312-32 [PMID:26215166]

59. Xu WD, Zhao Y and Liu Y. (2016) Role of the TWEAK/Fn14 pathway in autoimmune diseases. Immunol Res 64: 44-50 [PMID:26659091]

60. Yan M, Wang LC, Hymowitz SG, Schilbach S, Lee J, Goddard A, de Vos AM, Gao WQ and Dixit VM. (2000) Two-amino acid molecular switch in an epithelial morphogen that regulates binding to two distinct receptors. Science 290: 523-7 [PMID:11039935]

61. Yang CR, Hsieh SL, Ho FM and Lin WW. (2005) Decoy receptor 3 increases monocyte adhesion to endothelial cells via NF-kappa B-dependent up-regulation of intercellular adhesion molecule1, VCAM-1, and IL-8 expression. J Immunol 174: 1647-56 [PMID:15661928]

62. Yang CR, Hsieh SL, Teng CM, Ho FM, Su WL and Lin WW. (2004) Soluble decoy receptor 3 induces angiogenesis by neutralization of TL1A, a cytokine belonging to tumor necrosis factor superfamily and exhibiting angiostatic action. Cancer Res 64: 1122-9 [PMID:14871847]

63. Zhou T, Ichikawa K, Kimberley RP and Koopman WJ. (2001) An antibody selective for a tumor necrosis factor-related apoptosis-inducing ligand receptor and uses thereof Patent number: WO2001083560. 